\title{
NILAI-NILAI RELIGIUS DALAM NOVEL LELAKI YANG SANGAT MENCINTAI ISTRINYA KARYA MUHAMMAD B. ANGGORO
}

\author{
${ }^{1}$ Wa Ode Iin Dewi Sanreke, ${ }^{2}$ Amirudin Rahim dan ${ }^{3}$ La Ode Balawa \\ pbsi.fkip.uho@gmail.com \\ 1,2,3, Jurusan Pendidikan Bahasa dan Sastra Indonesia, \\ Fakultas Keguruan dan Ilmu Pendidikan, Universitas Halu Oleo \\ Kampus Hijau Bumi Tridharma Anduonohu, Kendari, Indonesia
}

\begin{abstract}
ABSTRAK
Tujuan yang ingin dicapai dalam penelitian ini adalah untuk mendeskripsikan nilai-nilai religius dalam novel Lelaki yang Sangat Mencintai Istrinya karya Muhammad B. Anggoro. Metode yang digunakan dalam penelitian ini adalah metode deskriptif kualitatif, yaitu peneliti berusaha mendeskripsikan data yang akan dianalisis berupa nilainilai religius dalam novel Lelaki yang Sangat Mencintai Istrinya karya Muhammad B. Anggoro. Sumber data dalam penelitian ini berupa novel Lelaki yang Sangat Mencintai Istrinya karya Muhammad B. Anggoro. Teknik pengumpulan data yang digunakan dalam penelitian ini adalah teknik baca-catat. Teknik analisis data dalam Menganalisis novel Lelaki yang Sangat Mencintai Istrinya karya Muhammad B. Anggoro, peneliti menggunakan empat tahapan teknik dalam menganalisis data yaitu sebagaiberikut; 1) mengidentifikasi data, 2) mengklasifikasi data, 3) mendeskripsikan data, 4) mengkaji/menganalisis data.

Hasil penelitian menunjukkan bahwa nilai-nilai religius dalam novel Lelaki yang Sangat Mencintai Istrinya karya Muhammad B. Anggoro yaitu terdapat enam aspek pokok; 1) penyerahan diri, tunduk, dan taat, 2) kehidupan yang penuh kemuliaan, 3) perasaan batin yang ada hubunganya dengan Tuhan, 4) perasaan berdosa, 5) perasaan takut, dan 6) mengakui kebesaran Tuhan.
\end{abstract}

Kata kunci: nilai, religius, novel 


\section{PENDAHULUAN}

Nilai religius merupakan hal yang penting yang harus diketahui oleh masyarakat namun seiring dengan berkembangnya jaman banyak masyarakat yang memandang bahwa nilai-nilai religius tidak begitu penting untuk dipelajari atau bahkan diketahui, karena lebih banyak hal menarik yang dapat dipelajari, padahal dalam ajaran nilai religius sangat penting untuk diterapkan dalam kehidupan seharihari, guna untuk mencapai kedamaian dan ketentraman dalam hidup. Selain pada pelajaran agama, nilai religius juga dapat disampaikan melalui sebuah karya sastra. Karya sastra adalah objek manusiawi, fakta kemanusiaan atau fakta kultural, sebab merupakan hasil ciptaan manusia. Meskipun demikian, karya itu mempunyai eksistensi yang khas yang membedakanya dari fakta kemanusiaan lainya seperti sistem sosial dan sistem ekonomi dan yang menyamakanya dengan sistem seni rupa, seni suara, dan sebagainya (Faruk, 2017: 77). Manfaat karya sastra diperoleh melalui nilai-nilai terrsirat, dibalik jalinan cerita yang disampaikan pengarang. Dengan membaca karya sastra, nilai-nilai tertentu akan meresap secara tidak langsung dibalik alur atau jalinan cerita yang secara apik ditampilkan.

Bentuk novel dalam kesusatraan merupakan sebuah sistem bentuk. Dalam sistem ini terdapat unsur-unsur pembentukya dan fungsi dari masingmasing unsur. Dalam sistem bentuk novel yang berupa cerita, terdapat unsur-unsur alur cerita (plot), penokohan, latar cerita (setting), permasalahan, suasana cerita dan sebagainya. Unsur-unsur ini membentuk sebuah struktur cerita besar yang diungkapkan lewat materi Bahasa. Novel adalah suatu jenis karya sastra yang berbentuk prosa fiksi dalam ukuran yang panjang (setidaknya 40. 000 kata dan lebih kompleks dari cerpen) dan luas yang di dalamnya menceritakan konflik-konflik kehidupan manusia yang dapat mengubah nasib tokohya. Novel mengungkapkan konflik kehidupan para tokohnya secara lebih mendalam dan halus. Selain tokohtokoh, serangkayan peristiwa dan latar ditampilkan secara tersusun hingga bentuknya lebih panjang dibandingkan dengan prosa rekaan yang lain (Wicaksono, 2017: 71).

Novel religius dapat menjadi jalan bagi penikmat sastra dalam mencari solusi permasalahan dalam kehidupan ini. Novel religius mampu menjadikan pembaca lebih arif dalam mengatasi permasalahan hidup. Saat ini novel religius cukup banyak diproduksi oleh sastrawan. Bahasa yang bersih dan santun menjadikan novel-novel religius mendapat tempat di hati masyarakat. Salah satu penulis novel dalam menulis sastra yang mengandung nilai religius adalah Muhammad $B$. Anggoro. Membaca novel-novel karya Muhammad B. Anggoro, pembaca tidak hanya sekedar mengalami peristiwa yang diuraikan tetapi lebih dari itu ada ruang rohaniyang terisi. Karya-karya Muhammad B. Anggoro mampu membuka cakrawala pembaca tentang religius yang di maksud adalah nilai-nilai religius karena dalam novelnya tersebut berisikan dan menceritakan tentang nilai agama yang diperlihatkan oleh pengarang melalui tokoh-tokohnya, latarnya, dan gaya bahasanya. Religius berhubungan dengan kedalaman penghayatan keagamaan seseorang dan keyakinan terhadap adanya Tuhan yang diwujudkan dengan mematuhi perintah dan menjauhi larangannya dengan penuh keikhlasan yang tertera dalam hati. Salah satu syarat dalam kehidupan yang amat penting adalah keyakinan yang menjelma sebagai agama.

Salah satu syarat dalam kehidupan yang amat penting adalah keyakinan yang menjelma sebagai agama. Agama itu bertujuan untuk mencapai kedamaian rohani dan kesejahteraan jasmani. Untuk mencapai kedua hal ini harus diikuti dengan syarat percaya dengan adanya Tuhan yang menciptakan semua yang ada di dunia ini. Orang-orang yang percaya 
dengan adanya Tuhan selalu merasa bahwa hidup di dunia ini hanyalah sementara. Tidak ada yang kekal di dunia ini kecuali Allah Yang Maha Sempurna. Semuanya terjadi secara siklus. Senang-susah dan susah-senang terus berganti. Kepercayaan itu berkembang seiring dengan perkembangan peradapan manusia itu sendiri. Pengalaman religius atau agama yang di alami seseorang dalam kehidupanya bisa menjadi inspirasi seseorang untuk menuliskanya dalam sebuah novel atau bentuk karya sastra lainya dengan memperhatikan nilai-nilai religius.

Karya sastra yang baik adalah karya sastra yang bisa mengungkapkan hakikat dan meningkatkan martabat kehidupan manusia. Pesan moral berbasis religiusmerupakan salah satu unsur pembangun karya fiksiyang dapat mempengaruhi aktualisasi satrawan dalam menciptakan karyanya. Karya sastra pada dasarnya memuat nilai religius. Salah satu karya sastra yang mengandung nilai religius adalah novel. Novel dalam penceritaannya banyak mengangkat peristiwa-peristiwa yang terjadi dalam masyarakat. Peristiwa tersebut tidak terlepas dari moral dan perilaku dalam masyarakat. Novel religius dapat menjadi jalan bagi penikmat sastra dalam mencari solusi permasalahan dalam kehidupan ini. Novel sebagai salah satu hasil sastra fiksi bersifat rekaan, namun novel ditulis berdasarkan kenyataan kehidupan sosial. Novel dapat mengungkapkan berbagai masalah, diantaranya kehidupan antar umat beragama dalam lingkup masyarakat. Hal ini bertujuan agar pembaca merasakan, menghayati kehidupan yang ada berbagai suatu masyarakat dan menjalani kepercayaanya ditengah peradaban lain. Oleh karena itu karya sastra sangatlah menarik untuk diteliti.

Pengalaman religius atau agama yang dialami seseorang dalam kehidupanya bisa menjadi inspirasi seorang pengarang untuk menuliskan dalam sebuah novel atau bentuk karya sastra lainya dengan memperhatikan nilai-nilaireligius. Oleh karena itu sastra dan agama mempunyai hubungan yang sangat erat. Sebab banyak diantara karya sastra yang merupakan sarana penyampaiaan nilai-nilai keagamaan dan salah satunya seperti yang ada dalam novel Lelaki yang Sangat Mencintai Istrinya karya Muhammad B. Anggoro. Nilai religius dalam karya sastra sangat diperlukan karena karya sastra tumbuh dari masyarakat yang bersifat religius. Dengan adanya nilai religius, dapat memberi kesadaran batin untuk membuat kebaikan, dan perlu ditanamkan kesadaran tentang pemahaman dan penghayatan terhadap nilai-nilai religiusterutama pada zaman globalisasi sekarang ini sangat diperlukan sebuah karya fiksi berupa novel yang memiliki nilai religius sebagai pembangun iman. Menurut Jauhari (2010: 33) nilai religius adalah nilai yang berhubungan dengan agama, keimanan seseorang, dan tanggapan seseorang terhadap nilai yang diyakini serta tindakan manusia yang memancarkan keimanan kepada Tuhan Yang Maha Esa.

Berdasarkan uraian latar belakang di atas, maka yang menjadi rumusan masalah dalam penelitian ini adalah bagaimanakah nilai-nilai religius yang terdapat dalam novel Lelaki yang Sangat Mencintai Istrinya karya Muhammad B. Anggoro?

Tujuan penelitian ini adalah untuk mendeskripsikan nilai-nilai religius yang terkandung dalam novel Lelaki yang Sangat Mencintai Istrinya karya Muhammad B. Anggoro.

Penelitian ini diharapkan mampu memberikan manfaat bagi para pembaca yakni:

1. Penelitian ini di harapkan dapat menambah pengetahuan dan wawasan pembaca mengenai nilai-nilai religius.

2. Penelitian ini diharapkan dapat memberikan masukkan kepada mahasiswa khususnya Program Studi Bahasa dan Sastra Indonesia dalam mengkaji dan menelaah novel. 
3. Dengan pemahaman nilai-nilai religius diharapkan akan menambah referensi penelitian karya sastra di Indonesia dan membantu pembaca dalam memahami makna yang terdapat dalam karya sastra.

4. Penelitian ini diharapkan bisa menjadi sumbangan pemikiran mengenai nilainilai religius dalam novel Lelaki yang Sangat Mencintai Istrinya karya Muhammad B. Anggoro.

Menurut Steeman (dalam Adisusilo, 20

13: 56) nilai adalah sesuatu yang memberi makna pada hidup, yang memberi acuan, titik tolak dan tujuan hidup. Nilai adalah sesuatu yang dijunjung tinggi, yang dapat mewarnai dan menjiwai tindakan seseorang. Nilai itu lebih dari sekedar keyakinan, nilai-nilai selalu menyangkut pola pikir dan tindakan, sehingga ada hubungan yang amat erat anatara nilai dan etika. Selanjutnya Adisusilo (2013: 56) juga mengemukakan bahwa merupakan referensi yang tercermin dari perilaku seseorang, sehingga seseorang akan melakukan atau tidak melakukan sesuatu tergantung pada sistem nilai yang dipegangnya.

Jadi, dapat disimpulkan bahwa nilai adalah suatu keyakinan ataupun perasaan yang diyakini sebagai suatu identitas yang memberikan corak yang khusus pada pemikiran, perasaan, keterikatan maupun perilaku manusia mengenai baik atau buruk yang diukur oleh agama, tradisi, etika, moral, dan kebudayaan yang berlaku dalam masyarakat.

Makna nilai dalam sastra menurut Waluyo (dalam Wicaksono, 2017: 322) adalah kebaikan yang ada dalam makna karya sastra bagi kehidupan seseorang. Hal ini berarti dengan adaya berbagai wawasan yang dikandung dalam karya sastra khususnya novel menunjukkan bahwa pada dasarnya suatu karya sastra akan selalu mengandung bermacam-macam nilai kehidupan yang akan sangat bermanfaat bagi pembaca. Sumardjo (1999: 3) lagi menyatakan bahwa nilai ideal pengarang berupa Das
Sollen pengarang tentang aspek-aspek nilai-nilai kehidupan, yakni dapat nilai moral, nilai agama, nilai politik, nilai kemasyarakatan dan sebagainya. Justru aspek nilai ideal inilah penyebab utama munculnya kreasi pengarang.

Berdasarkan pengertian tersebut, dapat ditarik kesimpulan bahwa yang dimaksud dengan nilai sastra, yaitu sifatsifat (hal-hal) atau merupakan sesuatu yang positif yang berguna dalam kehidupan manusia dan pantas untuk dimiliki tiap manusia, dalam pengertian ini, nilai adalah sesuatu yang berhubungan dengan etika (baik dan buruk), logika (benar dan salah), estetika (indah dan jelek).

Kata religi menurut asal kata berarti ikatan atau pengikatan diri. Jika sesuatu ada ikatan atau pengikatan diri, maka kata bereligi berarti menyerahkan diri, tunduk dan taat Atmosuwito (dalam Ariyadi, 2013: 8). Religi mengandung konsekuensi lurus, terang, jelas tidak ada penyamaran hitam putih, salah-benar, dosa, pahala dan semacamnya, sehingga menyematkan label agama pada karya sastra seperti sastra Islam, sastra Kristen dan sebagainya menjadi sebuah paradoks karena sekat yang ada antar keduanya (Irawan MN, 2013: 141).

Muhaimin dan Jufud Mudzakir (2005: 34) menjelaskan bahwa kata religi atau religion itu sendiri berasal dari bahasa latin, yang berasal dari kata relegere atau relegare. Kata relegare mempunyai pengertian dasar "berhati-hati" dan berpegang pada norma-norma atau aturan secara ketat. Dalam arti bahwa religi tersebut merupakan suatu keyakinan atau kepercayaan, nilai-nilai dan norma-norma hidup yang harus dipegangi atau dijaga dengan penuh perhatian, agar jangan sampai menyimpang dan lepas. Kata dasar relegare, berarti "mengikat", yang maksudnya adalah, mengingatkan diri pada kekuatan gaib yang suci. Kekuatan gaib tersebut diyakini sebagai kekuatan yang menentukan jalan hidup dan yang mempengaruhi kehidupan manusia. 
Dengan demikian kata religi tersebut pada dasarnya mempunyai pengertian sebagai "keyakinan akan adanya kekuatan gaib yang suci, yang menentukan jalan hidup dan mempengaruhi kehidupan manusia, yang dihadapi secara hati-hati dan diikuti jalan-jalan dan aturan-aturan serta normanormanya secara ketat, agar tidak sampai menyimpang dan lepas dari kehendak atau jalan yang telah ditetapkan oleh kekuatan gaib yang suci tersebut".

Dari uraian di atas dapat disimpulkan bahwa nilai religius adalah suatu pandangan/perasaan dalam memeluk dan menjalankan ajaran agama, serta sebagai cerminan diri atas ketaatan terhadap ajaran agama yang diaunutnya. Yang dimaksud dengan penyerahan diri ialah penyerahan diri kepada Yang Maha Kuasa. Tunduk kepada laranga-Nya dan taat kepada Perintah-Nya. Orang yang demikian termasuk orang yang takwa, karena pengertian takwa itu sendiri ialah menjauhi larangan-Nya dan melakanakan perintahNya. Kalau digolongkan pada aspek keagamaan, termasuk kepada Tauhid. Dalam masalah nilai religius, istilah tunduk dan taat itu tidak hanya ditunjukan kepada Yang Maha Kuasa, tetapi juga kepada lingkungan dan adatnya dimana mereka berada (Jauhari, 2010: 31)

Kehidupan yang penuh kemuliaan berhubungan dengan perilaku seseorang dalam melakukan kebaikan-kebaikan. Seseorang yang melakukan kebaikankebaikan atas dasar panggilan hati nuraninya sendiri, bukan karena mempunyai motif ingin dipuji apalagi karena ada unsur paksaan (Jauhari, 2010: 32).

Perasaan batin yang ada hubunganya dengan Tuhan ini berhubungan dengan tindakan keagaman bagaimana cara mendekatkan diri kepada Tuhan. Hal seperti ini dengan berbagai cara dilakukan sesuai agamanya masing-masing. Orang Islam di antaranya dengan sembahyang. Religius lebih melihat aspek yang "di dalam lubuk hati", riak getaran hati nurani pribadi, sikap personal yang sedikit banyak misteri bagi orang lain, karena menapaskan intimitasi jiwa, "dicoer" dalam arti pascal, yakni cita rasa yang mencakup totalitas ke dalam pribadi manusia (Jauhari, 2010: 32).

Seseorang menyadari kesalahaya, bahwa apa yang dilakukanya tidak sesuai dengan norma agama atau aturan-aturan yang telah digariskan oleh agama yang dianutnya dan adat-istiadat atau peraturanperaturan dilingkungannya (Jauhari, 2010: 32). Perasaan berdosa kepada Tuhan, yaitu sikap manusia yang merasa selalu diawasi oleh Tuhan sehingga pada saat melakukan suatu kesalahan ia akan merasa berdosa pada Tuhan dan berjanji tidak akan mengulangi kembali kesalahan-kesalahan serta dosa-dosa yang pernah dilakukan secara sadar (Wicaksono, 2017: 344).

Perasaan takut melakukan kesalahan, baik terhadap Allah maupun terhadap sesama manusia. Bahkan terhadap lingkunganya. Orang yang merasa takut melakukan kesalahan akan selalu berusaha melakukan kebaikan dan kebenaran. Selain itu, ia akan selalu ingat keterbatasan dan kerendahan dirinya dihadapan Allah. Karena dia tahu semua kesalahan yang dilakukannya pasti ada sanksinya baik di dunia maupun di akhirat kelak (Jauhari, 2010: 32-33). Takut kepada Allah, yaitu sikap manusia yang menyerahkan dirinya kepada Allah dan ia merasa takut akan segala kesalahanya kepada Allah (Wicaksono, 2017: 345).

Cara mengakui kebesaran Tuhan, bahwa seseorang merasa tidak ada apaapanya di hadapan Tuhan, mengakui kekuasaan Tuhan tidak ada batasnya. Manusia diciptakan Tuhan sebagai khalifa di bumi. Di sini terjadi perhambaan. Perhambahan Tuhan terjadi karena Tuhan menciptakan manusia. Adalah hak Sang Khalik sepenuhnya menuntut pengabdian manusia yang diciptakan-Nya sendiri (Jauhari, 2010: 33). Mengakui kebesaran Tuhan artinya bahwa seseorang merasa tidak ada apa-apanya, di hadapan Tuhan, mengakui kekuasaan Tuhan tidak ada batasnya dan sikap manusia yang percaya bahwa Tuhan itu Maha Besar dan Maha 
Berkuasa atas segala sesuatu. (dalam Meliyani, 2017: 19).

Novel ialah cerita yang panjang yang isinya menceritakan tokoh-tokoh pelaku dalam rangkayan peristiwa dengan latar yang tersusun dan teratur. Istilah lainya ialah roman. Akhir-akhir ini kita menyamakan pengertian novel dengan roman, karena pengaruh kesusastraan yang kita terima dari Inggris. Dalam kesusatraan Inggris tidak dijumpai roman. Yang mereka gunakan ialah novel yang tidak lain ialah roman (Hendy, 1991: 57). Dahulu istilah roman kita dari kesusastraan Belanda, sehingga kita mengenal roman dan membedakan roman dengan novel. Disebutkan bahwa roman ialah karya yang mengisahkan para pelaku secara panjang lebar, sejak kanak-kanak sampai dewasa bahkan sampai meniggal dunia. Novel berasal dari bahasa Italia novella (yang dalam bahasa Jerman: NovellaI). Secara harfiah Novella berarti 'sebuah barang baru yang kecil', dan kemudian diartikan sebagai 'cerita pendek dalam bentuk prosa' Abrams (dalam Nurgiantoro, 20013: 11-12). Sumardjo (1999: 129) juga menjelaskan bahwa novel ditulis dan diterbitkan agar dibaca, sebab novel adalah salah satu bentuk ungkapan atau ekspresi dalam sastra untuk dikomunikasikan kepada orang lain.

Wicaksono (2017: 71) menyatakan bahwa novel adalah suatu jenis karya sastra yang berbentuk prosa fiksi dalam ukuran yang panjang (setidaknya 40. 000 kata dan lebih kompleks dari cerpen) dan luas yang di dalamnya menceritakan konflik-konflik kehidupan manusia yang dapat mengubah nasib tokohya.

Jadi, dapat disimpulkan bahwa novel adalah sutu bentuk komunikasi yang disampaikan dalam bentuk cerita dengan menggunakan tulisan, dimana cerita itu diperoleh dari serangkaian atau sebuah imajinasi bahkan pengalaman yang dirasakan oleh pengarang sehingga dijadikan dalam sebuah cerita.

Unsur intrinsik sebuah novel adalah unsur-unsur yang (secara lansung) turut serta membangun cerita. Kepaduan antar berbagai unsur intrinsik inilah yang membuat sebuah novel berwujud. Atau sebaliknya, jika dilihat dari sudut kita pembaca, unsur-unsur (cerita) inilah yang akan dijumpai jika membaca sebuah novel. Unsur yang dimaksud, untuk menyebut sebagian saja misalnya, peristiwa, cerita, plot, penokohan, tema, latar, sudut pandang penceritaan, bahasa atau gaya bahasa, dan lain-lain (Nurgiyantoro, 2013: $30)$.

Herman J. Waluyo (dalam Wicaksno, 2017: 93) menyatakan bahwa unsur intrinsik adalah kemampuan kesanggupan seseorang untuk menguasai unsur-unsur yang membangun suatu kesatuan, kebulatan kesatuan, dan regulasi diri atau membangun sebuah struktur.

Unsur-unsur itu bersifat fungsional, artinya dicipta pengarang untuk mendukung maksud secara keseluruhan dan maknanya ditentukan oleh keseluruhan cerita itu. Redaksi PM (2012: 4-5) juga menjelaskan bahwaunsur intrnsik ialah unsur yang menyusun sebuah karya sastra dari dalam yang mewujudkan struktur suatu karya sastra. Seperti: tema, tokoh dan penokohan, alur dan pengaluran, latar dan pelataran, dan pusat pengisahan.

Jadi,dapat disimpulkan bahwa unsur intrinsik adalah unsur yang terkandung dari dalam karya sastra,yang mewujudkan struktur sebuah karya sastra seperti tema, amanat, alur atau plot, perwatakan atau penokohan, latar atau setting, sudut pandang, dan gaya bahasa.

Tema adalah pokok pengisahan dalam sebuah cerita. Cerita atau karya sastra yang bermutu tidak lain karya sastra yang bertema baik, yaitu dapat mengubah pandangan dan perilaku yang negatif menjadi positif (Hendy, 1991: 31-32). Peristiwa yang diungkapkan dalam karya sastra itu mengandung masalah. Masalah itu banyak sekali. Sebuah cerita yang baik akan membahas masalah utamanya saja. Ceritanya memang bervariasi dengan masah-masalah kecil lainya. Tetapi tetap terfokus kepada masalah utama atau 
kepada tema. Tema yang kita jumpai dalam karya sastra banyak sekali. Ada tema perjuangan, kebangsaan, kemasyarakatan, ketuhanan, kemanusiaan, dan sebagainya. Tema-tema tersebut cukup luas. Sebaiknya rumusan tema itu dipersempit. Misalnya: perjuangan menegakkan kebenaran pada akhirnya akan berhasil. Kejayaan bangsa kita akan cepat tercapai bila kita semua menyingsikan lengan baju.

Nurgiantoro (2013:115) menyatakan bahwa tema adalah gagasan (makna) dasar umum yang menopang sebuah karya sastra sebagai struktur semantis dan bersifat abstrak yang secara berulang-ulang dimunculkan lewat motif-motif dan biasanya dilakukan secara implisit. Tema merupakan aspek cerita yang sejajar dengan 'makna' dalam pengalaman manusia., sesuatu yang menjadikan suatu pengalaman yang begitu diingat. Ada banyak cerita yang menggambarkan dan menelaah kejadian atau emosi yang dialami manusia seperti cinta, derita, rasa takut, kedewasaan, keyakinan, penghianatan manusia terhadapa diri sendiri, disilusi, atau bahkan usia tua (Stanton, 2012: 36-37). Selanjutnya menurut Sayuti (2017: 199) juga mengemukakan bahwa tema adalah makna cerita, gagasan sentral, atau dasar cerita.

Sebuah cerita umumnya berpola sebagai berikut: perkenalan keadaan, perkembangan, krisis, klimaks, penyelesaiyan. Variasinya bermacammacam, tetapi tetap mempunyai pertalian dan hubungan yang wajar. Tidak terlepas dan tidak terpisah antara bagian cerita terdahulu dengan bagian cerita kemudian. Pertalian mata rantai bagian-bagiancerita inilah yang disebut aluratau plot (Hendy, 1991: 32).

\section{Nurgiantoro}

(2013:

menjelaskan bahwa plot merupakan unsur fiksi yang penting, bahkan tidak sedikit orang yang menganggapnya sebagai yang terpenting diantara berbagai unsur fiksi yang lain. Stanton (2012: 26) juga mengemukakan bahwa secara umum, alur merupkan rangkayan peristiwa-peristiwa dalam sebuah cerita. Istlah alur biasanya terbatas pada peristiwa-peristiwa yang terhubung secara kausal saja.

Penokohan atau perwatakan ialah teknik atau cara-cara menampilkan tokoh. Ada beberapa cara menampilkan tokoh. Cara analitik, ialah cara penampilan tokoh. Cara analitik, ialah cara menampilkan tokoh secara langsung melalui urayan pengarang. Jadi pengarang menguraikan cirri-ciri tokoh tersebut secara langsung (Redaksi PM, 2012: 6).

Latar (setting) ialah segala keterangan mengenai waktu, ruang dan suasana yang diceritakan dalam sebuah karya sastra atau sebuah novel. Latar belakang (background) ialah keadaan sosial, sejarah, dan sebagainya yang menjelaskan cerita dalam sebuah karya sastra (Hendy, 1991: 33-34). Sudut pandang atau titik tinjau adalah tempat atau posisi pencerita terhadap kisahan yang dikarangnya. Apakah ia ada di dalam cerita, atau ia ada di luar cerita itu (Hendy, 1991: 34).

Sudut pandang dalam kesusastraan menuru t Hendy (1991: 34-35) mencakup:

1. Sudut pandang fisik, yaitu sudut pandang yang berhubungan dengan waktu dan ruang yang digunakan pengarang dalam pendekatan materi ceritanya.

2. Sudut pandang mental, yaitu sudut pandang yang berhubungan dengan perasaan dan sikap pengarang terhadap masalah atau peristiwa yang diceritakanya.

3. Sudut pandang pribadi, yaitu sudut pandang yang menyangkut hubungan atau keterlibatan pribadi pengarang dalam pokok masalah yang diceritakanya.

Gaya bahasa (figures of speech) menurut Weren and Martin (dalam Siswantoro 2016: 115) adalah penyimpangan bentuk ungkapan bisa atau penyimpangan dari jalan pikiran lumrah dalam upaya memperoleh efek yang lebih intens. Gaya bahasa (figures of speech) adalah suatu gerak membelok dari bentuk 
ekspresi sehari-hari atau aliran ide-ide yang biasa untuk menghasilkan suatu efek yang luar biasa (Siswantoro, 2016: 115). Penggunaan gaya bahasa terjadi di dalam dunia puisi sebab kata-kata denotatif memiliki keterbatasan. Dengan mengandalkan makna lugas harfiah semata dalam deskripsi objek atau ide, seorang penyair akan menemui rintangan.

Gaya bahasa (figures of speech) adalah suatu gerak membelok dari bentuk ekspresi sehari-hari atau aliran ide-ide yang biasa untuk menghasilkan suatu efek yang luar biasa (Siswantoro, 2016: 115).

Jauhari (2010: 115) mengungkapkan bahwa unsur ekstrinsik adalah unsur yang berada di luar karya sastra, tetapi mempengaruhi dan menentukan sebuah penciptaan karya sastra. Pengarang menciptakan sebuah karya sastra karena ada dorongan dari unsur ekstrinsik. , menentukan jenis karya sastra juga karena ada dorongan dari unsur ekstrinsik. Unsur ekstrinsik ialah unsur yang menyusun sebuah karya sastra dari luarnya menyangkut aspek sosiologi, psikologi, dan lain-lain (Redaksi PM, 2012:5). Kemudian menurut Herman J. Waluyo (dalam Wicaksono, 2017: 93) juga mengemukakan bahwa unsur ekstrinsik adalah unsur-unsur yang berada di luar karya sastra, tetapi secara tidak langsung mempengaruhi bangunan atau sistem organisme karya sastra.

Jadi, dapat disimpulkan bahwa unsur ekstrinsik adalah sebuah karya sastra yang berada di luar sastra yang memengaruhi kelahiran dan keberadaan suatu karya sastra itu sendiri dan mempermudah memahami karya sastra tersebut. Unsur ini membuat suatu karya sastra memiliki nilai dan terikat hubungan tersendiri dalam sosial masyarakat.

Jenis penelitian yang digunakan dalam penelitian ini adalah penelitian kepustakaan (library research) yaitu dengan jalan mengadakan studi lewat sejumlah bahan bacaan atau referensireferensi yang ada, baik berupa naskah novel maupun dari sumber-sumber buku penunjang lainya khususnya yang mencakup serta mendukung penelitian ini.

Metode yang digunakan dalam penelitian ini adalah metode deskriptif kualitatif. Metode deskriptif diartikan sebagai prosedur pemecahan masalah yang diteliti dengan menggambarkan atau melukiskan keadaan objek penelitian dalam hal ini adalah nilai-nilai religus berdasarkan fakta-fakta yang ditentukan sebagaimana adanya.

Penelitian kualitatif pada hakikatnya adalah penelitian yang berusaha mengamati, memahami dengan tujuan untuk memperoleh pemahaman makna. Penelitian ini mendeskripsikan data yang akan dianalisis berupa nilai-nilai religius dalam Novel Lelaki yang Sangat Mencintai Istrinya karya Muhammad B. Anggoro.

Data yang digunakan dalam penelitian ini adalah data tertulis berupa teks novel yang berkaitan dengan nilainilai religius dalam novel Lelaki yang Sangat Mencintai Istrinya tentang penyerahan diri, tunduk, dan taat, kehidupan yang penuh kemuliaan, perasaan batin yang ada hubungannya dengan Tuhan, perasaan berdosa, perasaan takut, dan mengakui kebesaran Tuhan.

Sumber data dalam penelitian ini adalah buku novel itu sendiri dalam hal ini adalah novel Lelaki yang Sangat Mencintai Istrinyakarya Muhammad B. Anggoro terbitan DIVA Press cetakan pertama tahun 2012, dengan tebal 350 halaman.

Teknik pengumpulan data yang digunakan dalam penelitian ini adalah teknik baca-catat, dimana peneliti membaca naskah novel Lelaki yang Sangat Mencintai Istrinya karya Muhammad B. Anggoro secara berulang-ulang, setelah itu mencatat data-data yang diperoleh dari hasil bacaan, kemudian menentukan hasil yang diperoleh dari hasil pembacaan yang berkaitan dengan nilai-nilai religius yang diteliti.

Dalam menganalisis novel Lelaki yang Sangat Mencintai Istrinya karya Muhammad B. Anggoro dalam penelitian 
ini, peneliti melihat nilai-nilai religius yang terdiri atas penyerahan diri, tunduk, dan taat, kehidupan yang penuh kemuliaan, perasaan batin yang ada hubungannya dengan Tuhan, perasaan berdosa, perasaan takut, dan mengakui kebesaran Tuhan.

Selengkapnya teknik analisis data yang dimaksud, dilakukan dengan tahapan berikut ini:

1. Mengidentifikasi data, artinya membaca secara keseluruhan novel dan memberi kode pada data yang sesuai dengan permasalahan penelitian.

2. Mengklasifikasi data, yaitu mengelompokkan data berdasarkan permasalahan dalam penelitian ini dengan menyertakan pernyataan berupa kalimat yang menggambarkan nilainilai religius dalam novel Lelaki yang Sangat Mencintai Istrinya karya Muhammad B. Anggoro.

3. Mendeskripsikan data, yaitu data hasil analisis ditafsirkan ke dalam bentuk paparan kebahasaan. Dalam hal ini kutipan-kutipan yang tergolong sebagai gambaran sebuah nilai-nilai religius, kemudian dijabarkan secara detail disertai dengan kutipan-kutipan sebagai pendukung permasalahan.

4. Mengkaji/menganalisis data, yaitu menafsirkan isi cuplikan yang diambil dari novel yang telah di identifikasi dengan kaitanya atau hubungan dengan nilai-nilai religius dalam novel Lelaki yang Sangat Mencintai Istrinya karya Muhammad B. Anggoro.

\section{HASIL PENELITIAN}

Novel L elaki yang sangat Mencintai Istrinya ini menceritakan tentang seorang lelaki yang bernama Puan, seorang pria dari Desa Kendum Arum, telah tigah tahun lebih menantikan kedatangan Puri istrinya, yang bekerja sebagai buruh migran di Hogkong. Selama istrinya berada di Hongkong Puan setiap hari selalu meyempatkan membaca Alquran, tidak jarang, ia membaca sampai setengah juz. Kebiasaanya membaca Alquran ini pulalah yang menenangkan hatinya selama ditinggal Puri bekerja diluar negeri. Setiap kali ia diserang rasa rindu yang semakin memuncak atau setiap kali merasa sangat kesepian, maka Puan lebih banyak memilih menghabiskan waktunya dengan membaca Alquran. Biasanya, setelah membaca Alquran, hatinya menjadi tenang, dan nyaman walaupun sebenarnya ia sedang mempunyai masalah yang berat dan serius. Ia berharap dengan kepulangan Puri, mereka dapat merajut benang-benang cinta dalam rumah tangga kembali. Penantianya berunjung. Istrinya kini telah pulang dari Hongkong. Kepergian Puri ke Hongkong yang sempat ditentang Puan, karena menurutnya telah mempertaruhkan keutuhan rumah tangga mereka ternyata terbukti. Sepulangnya dari Hongkong, sikap Puri berubah.

Nilai religus dalam novel Lelaki yang Sangat Mencintai Istrinya karya Muhammad B. Anggoro dalam penyerahan diri, tunduk dan taat tergambar ketika Puan menyerahkan diri, pasrah, tawakkal, dan tunduk patuh atas segala Rencana dan Kuasa Allah Swt atas segala masalah yang dihadapinya. Seperti pada kutipan isi novel berikut ini.

"Ya Allah, ya Tuhanku! Sesungguhnya ada hikmah apakah yang sedang Kau sembunyikan dari hamba-Mu ini, ya Allah? Sungguh hamba tidak tahu, benarbenar tidak tahu. Karena sesungguhnya, engkaulah yang Maha Berencana lagi Maha Berkuasa. Oleh karena itu, hambah pasrah, tawakkal, dan tunduk patuh atas segala Rencana dan Kuasa-Mu. Semua urusan yang tengah membelit hamba, hambah pasrahkan sepenuh-penuhnya padamu, ya Allah. .." Suara tangisan Puan terdengar semakin memiluhkan. Tak ada pilihan lain, hanya kepada Allah, ia berserah diri. Hanya kepada-Nya, Ia menyerahkan segala persoalan yang tengah membelenggunya. "Ya Allah, ya Tuhanku! Kini, Engkau tahu persoalan yang tengah membelunggu hamba. Istri hamba sekarang ini entah menginap di mana. Entah pula dengan siapa. Sungguh, demi Engkau, penguasa Bumi dan Langit, 
hamba tidak ridha, hamba tidak ikhlas. Hamba benar-benar merasa terzhalimi oleh istri hamba sendiri. Oleh karena itu, kini, hamba memohon kepada-Mu, memohon kebijaksanaan-Mu dan keadilan-Mu. Tunjukkanlah yang benar adalah benar dan yang salah adalah salah. Tunjukkanlah, ya Allah! Tunjukkanlah! Karena sesungguhnya, Engkaulah Yang Maha Bijaksana, Engkaulah Yang Maha Adil lagi Maha Kuasa...". (Anggoro, 2012:212-214).

Berdasarkan kutipan isi novel tersebut seorang Puan memiliki nilai religius yakni penyerahan diri, tunduk, dan taat. Puan benar-benar menyerahkan diri tunduk dan taat kepada Allah Swt atas apa yang menjadi segala Rencana dan KuasaNya. Puan pasrahkan semuah masalah yang menimpah dan membelit rumah tangganya kepada Tuhanya karena istrinya Puri tengah menginap dengan pria lain. Hal ini merupakan pukulan yang teramat sakit, benar-benar terasa sakit apa yang dirasakan oleh Puan saat itu. Puan benarbenar terpuruk dan tidak ridha atas apa yang tengah dilakukan istrinya. Ia benarbenar merasa telah terzhalimi oleh istrinya sendiri.

Religius yang terdapat dalam novel Lelaki yang Sangat Mencintai Istrinya karya Muhammad B. Anggoro dapat dilihat dari tergambarnya dalam kehidupan yang penuh kemuliaan. Rasa cinta dan kasih sayang Puan terhadap istrinya adalah perbuatan yang mulia. Kehidupan yang penuh kemuliaan di gambarkan oleh Puan ketika ia memberikan nasehat terhadap istrinya agar lebih baik lagi dan segera menghilangkan tabiat-tabiat buruknya itu. Sehingga di akhirat kelak ia dan istrinya dapat bertetangga dengan Allah. Seperti pada kutipan isi novel berikut ini.

Mendadak Puri diam membisu. Memandang langit-langit kamar. Entah apa yang sedang dipikirkanya saat itu. Puan pun kembali menasihatinya. Karena ia pikir, inilah saat yang paling tepat menasihati Puri yang jelas-jelas mulai Nusyu terhadapnya. "Coba perhatikan dan pikirkan baik-baik sabdah rasulullah Saw. Bahwa sebaik-baik harta seseorang yaitu wanita shalihah yang bila suaminya memandang, menyenagkan suaminya; bila suami memerintahkan kepadanya, ia menaati; dan bila suaminya tidak ada di tempat, ia memelihara kehormatan. "Itulah hal-hal penting yang harus kamu lakukan, istriku. Tentunya jika kita ingin menjadi suami istri yang kekal abadi, yaitu tetap menjadi suami istri, bukan hanya menjadi suami istri di dunia ini semata, melainkan juga menjadi suami istri hingga nanti kita di surga. Itulah visi terbesarku dalam membinah rumah tangga denganmu. Karena apa? Karena aku terlalu sangat mencintaimu, istriku." (Anggoro, 2012: 188-189).

Pada kutipan isi novel tersebut terlihat bahwa seorang Puan memiliki sifat religius yakni kehidupan yang penuh kemuliaan, yaitu tergambar ketika Puan sedang memberikan nasehat terhadap istrinya agar lebih baik lagi. Ia melakukan itu senantiasa hanya untuk menyadarkan istrinya agar selalu bertakwa kepada Allah Swt yaitu dengan memberikan nasihat dan dorongan yang membangun istrinya sesuai dengan apa yang menjadi pengetahuanya tentang sifat dan akhalak Aisya. Maka dari itu Puan ingin sekali mengajak istrinya agar lebih baik lagi dan segera meninggalkan tabiat-tabiat buruknya itu. Puan memiliki visi yang amat besar, dimana ia menginginkan dirinya dan istrinya Puri menjadi suami istri yang kekal abadi, yaitu tetap menjadi suami istri bukan hanya di dunia saja, melainkan juga menjadi suami istri hingga nanti di Surga kelak, karena ia terlalu mencintai dan menyayangi istrinya.

Religius yang tercermin dalam novel Lelaki yang Sangat Mencintai Istrinya dapat terlihat dari tergambarnya rasa batin yang ada hubunganya dengan Tuhan lewat beberapa kutipan dalam isi novel. Perasaan batin yaaang ada hubunganya dengan tuhan yang digambarkan oleh Puan yaitu pada saat ia mulai dapat mengendalikan dirinya atas perasaan 
terlukanya terhadap istrinya. Karna ia yakin, hanya Tuhanlah yang mampu menyembuhkan luka hatinya. Seperti pada kutipan isi novel sebagai

berikut ini.

"Walau, belum sepenuhnya dapat mendidih perasaan terlukanya, namun setidak-tidaknya, ia mulai dapat mengendalikan dirinya. Karena ia yakin, hanya Tuhanlah yang mampu menyembuhkan luka hatinya. Tak perlu ada yang perlu diragukan lagi. Karena itu, ia tak bosan-bosanya mengadu kepada Tuhanya. Hanya kepada Tuhanya pulalah ia memohon pertolongan-Nya. Hanya kepada Engkaulah kami menyembah dan hanya kepada Engkaulah kami memohon pertolongan. Namun, rasanya itu semua belum cukup. Puan masih ingin mengadu lagi dengan Tuhan. Rasanya tak cukup hanya dengan bermunajat dan berdoa, ia mulai meraih mushaf al-Qur'anya itu, seketika terbuka lembaran-lembaran mushaf al-Qur'an yang belum dibacanya. Ia hanya terus membaca lembaran demi lembaran mushaf Alquranya itu sampai dia benar-benar merasa letih. Tak sanggup lagi meneruskan membaca lembaranlembaran mushaf Alquranya itu hingga tak berapa lama kemudian, Puan merebahkan tubuhnya di ranjang dengan segenapa keletihanya jiwanya, hingga akhirnya ia tertidur. (Anggoro, 2012: 214-216).

Berdasarkan kutipan isi novel tersebut, bahwa seseorang memiliki perasaan batin yang ada hubunganya dengan Tuhan, yaitu tergambar pada Puan yang menggambarkan perilaku seorang manusia yang menyampaikan keluh kesahnya kepada Tuhan dengan berbicara dalam batinnya, yaitu pada saat Puan belum sepenuhnya mendidih perasaan terlukanya, namun setidak - tidaknya, ia mulai dapat mengendalikan dirinya. Karena ia telah berdoa dan bermunajat serta telah membaca lembaran-lembaran mushaf Aquranya, dengan hal itu ia mulai sedikit tenang dan tidak risau lagi. Karena ia yakin, hanya Tuhanlah yang mampu menyembuhkan luka hatinya. Tidak perlu ada yang perlu diragukan lagi atas kekuatan Tuahanya Allah Swt. Karena itu, ia tidak pernah ada bosan-bosanya mengadu kepada Tuhanya atas masalah yang dihadapinya.

Nilai religius dalam perasaan berdosa yang dirasakan oleh Puan, yaitu digambarkan ketika Puan memikirkan istrinya yang semakin hari semakin nusyu dan cenderung berbuat semaunya sendiri. Padahal, salah satu syarat untuk menjadi tetangga Allah itu nanti hanyalah untuk orang-orang yang beriman, orang yang ahli ibadah, bukanya orang yang ahli maksiat. Hal ini dapat di lihat seperti kutipan berikut ini.

"Istrinya jelas-jelas semakin nusyu dan cenderung berbuat semaunya sendiri. Lupa dengan anak dan suami sendiri. Lupa juga dengan tanggung jawabnya sebagi seorang istri. Jika demikian, bagaimana mungkin istrinya bisa diajak menjadi istrinya hingga di alam akhirat nanti? Bagaimana mungkin pula ia dapat mengajak istrinya bertetangga dengan Allah kalau istrinya sedikit pun juga tidak mau mengubah tabiat-tabiat buruknya? Padahal, salah satu syarat untuk menjadi tetangga Allah itu nanti hanyalah untuk orang-orang yang beriman, orang yang ahli ibadah, bukanya orang yang ahli maksiat. Lalu, bagaimana pula dengan istrinya? Lagi-lagi, Puan hanya bisa mendesah. Keresahanya kali ini benar-benar membuatnya sesak $n$ apas. Tak tahu lagi bagaimana cara menyadarkan istrinya yang dari hari ke hari semakin kurang ajar, semakin berani, dan semakin durhaka terhadap dirinya. (Anggoro, 2012: 169).

Berdasarkan kutipan isi novel tersebut, terdapat nilai religius yang memiliki perasaan berdosa yang tergambar pada saat Puan memikirkan istrinya yang tidak pernah mengubah akan tabiat-tabiat buruknya semakin nusyu dan cenderung berbuat semaunya sendiri. Padahal, salah satu syarat untuk menjadi tetangga Allah itu nanti hanyalah untuk orang-orang yang beriman, orang yang ahli ibadah, bukanya orang yang ahli maksiat. Puan sangat 
gelisah memikirkan hal itu, ia merasa berdosa kepada Allah akan perbuatan istrinya karena ia tidak bisa menjadikan istrinya sebagai wanita salihah. Lagi-lagi, Puan hanya bisa mendesah. Keresahanya kali ini benar-benar membuatnya sesak napas.

Nilai religius yang memiliki perasaan takut dalam novel Lelaki yang Sangat Mencintai Istrinya karya Muhammad B. Anggoro, yang dirasakan oleh Puan, digambarkan ketika ia merasa ragu jika ia sampai melakuan kekerasan terhdap istrinya. Jangan sampai ia dikena pasal undang-undang kekerasan dalam rumah tangga jika ia sampai memukul istrinya, dan ia merasa bimbang atas ketetapan Allah Swt yang pernah di jelaskan oleh guru ngajinya waktu itu. Seperti terlihat pada kutipan isi novel berikut ini:

"Saking kesalnya, tak tahan menahan amarahnya saat itu, hampir saja Puan memukul istrinya. Namun, tiba-tiba Puan jadi ragu. Kalau istrinya melaporkanya kepada polisi, maka urusanya malah bisa bertambah runyam. Ia bisa dikena pasal undang-undang kekerasan dalam rumah tangga (UU KDRT). Mau tidak mau, Puan harus menangguhkan kemarahanya. Terpaksa, ia harus mengurunkan kekerasan terhadap istrinya, walau hanya sekedar memberinya pelajaran. Sebenarnya, Puri sudah jelas-jelas nusyu terhadapnya. Akan tetapi, di sisi lain, Puan merasa bingung, bimbang, sekaligus penasaran manakala ia teringat firman Allah Ta'ala. "Istri-istri yang kamu khawatirkan nusyu, maka nasihatilah mereka dan berpisah diri dari tempat tidur mereka, dan pukullah mereka. Kemudian, jika mereka menaatimu, maka jangan kamu mencari-cari jalan untuk menyusahkan mereka. Sesungguhnya Allah Maha Tinggi lagi Maha Besar. " Guru mengajinya juga pernah menjelaskan bahwa Rasulullah Saw. Pernah bersabda seperti yang diriwayatkan oleh Muslim. "Takutlah kepada Allah dalam urusan wanita. Karena sesungguhnya kalian mengambil mereka dengan amanat Allah dan dihalalkan bagi kalian mencampuri mereka dengan rahmat Allah. " (Anggoro, 2012: 193-194).

Pada kutipan isi novel tersebut terdapat nilai religius yang memiliki perasaan takut yang dialami oleh Puan, yaitu tergambar pada saat Puan hampir saja memukul istrinya tapi ia takut akan dikena pasal undang-undang kekerasan dalam rumah tangga (UU KDRT). Apa lagi ia takut akan Tuhanya yaitu Allah Swt karenah ia mengingat akan penjelasan dari guru ngajinya, yang menjelaskan bahwa Rasulullah Saw. Pernah bersabda seperti yang diriwayatkan oleh Muslim, yaitu "Takutlah kepada Allah dalam urusan wanita. Karena sesungguhnya kalian mengambil mereka dengan amanat Allah dan dihalalkan bagi kalian mencampuri mereka dengan rahmat Allah". Jadi pada kutipan tersebut menggambarkan perilaku manusia yang merasa takut dengan Tuhanya, dikarenakan dalam agama tidak boleh melakukan kekerasan terhadap seorang Istri apa lagi kekerasan dengan melukai, hal itu sangat dilarang oleh Allah Swt. Apabila manusia percaya bahwa Tuhan melihat segala aktivitas hambanya yang tidak dapat dilihat oleh manusia maka ia akan merasa takut dan tidak akan berani melakukan perbuatan dosa karena ia merasa selalu diawasi oleh Tuhan.

Religius yang tercermin dalam novel Lelaki yang Sangat Mencintai Istrinya terlihat dari tergambarnya mengakui kebesaran Tuhan tergambar ketika Puan sedang mengantar temanya Kodir, padahal dalam perjalanan itu tak sengaja Puan melihat istrinya di sebuah warung bersama seorang lelaki yang sedang merokok, sungguh Puan benar-benar melihat keajaiban dan kebesaran Allah yang akhirnya memperlihatkan kebenaran yang sejelas-jelasnya, yang selama ini ia selalu pikirkan dan selalu meresahkan batinya. Lebih tepatnya dapat dilihat pada kutipan isi novel berikut ini.

"Akan tetapi, sewaktu Kodir baru saja membelokkan mobilnya ke kiri di daerah 
bandungan, tiba-tiba Puan memekik. "Astagfirullah hal'azhim! Masya Allah!". "Ada apa, Puan? Kenapa kamu berteriakteriak seperti orang gila begini?" Ujar Kodir, panik. "Berhenti, Dir! Berhenti!" Tanpa banyak tanya lagi, Kodir menghentikan mobilnya dibahu kiri jalan. Sementara itu, Puan tak henti-hentinya terus memperhatikan seorang wanita cantik yang sedang bercakap-cakap disebuah warung rokok di seberang jalan depan sana. "Allahu Akbar! Allahu Akbar! Allahu Akbar! Demi Allah! Aku benarbenar seperti melihat kuasa Allah di depan mataku, Dir! Lihat, Dir! Lihat!" pekik Puan lagi semakin menggila. Kodir ikutikutan panik. Ia pun segera mengikuti arah telunjuk jari temanya itu. "Lihat, Dir! Lihat! Siapa perempuan itu, Dir? Siapa? Siapa? Ia itu Puri, Dir! Puri istriku, Dir!" Puan terus berteriak-teriak persis seperti orang gila. Telunjuk jarinya pun terus menunjuk-nunjuk ke arah Puri istrinya, yang sedang bercakap-cakap dengan seorang pria di depan warung rokok itu. "Sungguh! Maha Besar Allah, Dir! Maha Besar Allah! Akhirnya, kebenaran diperlihatkan oleh Allah di depan mataku, Dir. Ternyata, istriku tidak menginap di Muntilan, tetapi di bandungan ini, Dir. "Demi Allah! Ini adalah keajaiban dari Tuhan, Dir. Keajaiba-Nya yang memang telah direncanaka-Nya untuk memperlihatkan kebenaran dengan seterang-terangnya. Inilah berkat doa dan munajatku semalam, Dir. Akhirnya bau bangkai tercium juga!”. (Anggoro, 2012: 228-230).

Pada kutipan isi novel tersebut terdapat nilai religius yang memiliki sifat tokoh mengakui kebesaran Tuhan yang dirasakan oleh Puan, yaitu tergambar ketika Puan pergi menemani temanya Kodir untuk menemui pacarnya. Akan tetapi, sewaktu Kodir baru saja membelokkan mobilnya ke kiri di daerah bandungan, tiba-tiba Puan memekik dengan kerasnya karena perasaan kaget melihat sebuah keajaiban di depan matanya sendiri. Sungguh Puan benarbenar melihat kuasa Allah di depan matanya sendiri. Keajaiba-Nya yang memang telah direncanaka-Nya untuk memperlihatkan kebenaran dengan seterang-terangnya. Akhirnya Puan mulai tenang akan kebenaran yang ia lihat pada saat itu. Sungguh Puan benar-benar mengakui kebesaran Tuhanya dengan sangat bahagianya karena kebenaran ia sudah dapatkan. Jadi, dengan kutipan isi novel tersebut dapat dilihat bahwa Tuhanlah yang bisa melakukan apapun sesuai dengan kehendaknya sehingga hambanya dapat membuktikan kebesaranNya. Manusia akan melihat kejadiankejadian di alam semesta ini atau bahkan dalam situasi yang kita tidak dapat ketahui, sehingga Allah dapat membuktikanya agar manusia percaya bahwa dirin-Nya memang benar-benar ada.

\section{KESIMPULAN}

Berdasarkan pembahasan hasil penelitian, dapat disimpulkan bahwa nilainilai religus yang terdapat dalam novel Lelaki yang Sangat Mencintai Istrinya karya Muhammad B. Anggoro mencakup enam aspek pokokyaitu:

1) Penyerahan diri, tunduk, dan taat, yaitusebagai bentuk penghambaan manusia kepada Allah Swt. Penyerahan diri merupakan makna yang terkandung dalam Islam. Artinya, sebagai hamba Allah, manusia harus berserah diri dan tunduk kepada-Nya atas segala ketetapan, perintah, dan laranga-Nya. Segala bentuk penyerahan diri manusia kepada Allah Swt dilakukan dengan mengikuti seluruh perintah-Nya dan menjauhi segala laranga-Nya.

2) Kehidupan yang penuh kemuliaan,yaitu berhubungan dengan perilaku seseorang dalam melakukan kebaikan-kebaikan. Seseorang melakukan kebaikankebaikan atas dasar panggilan hati nuraninya sendiri hanya ingin mendapatkan keridhoan dari Allah Swt, bukan karena mempunyai motif ingin dipuji oleh manusia apalagi karena ada unsur paksaan. 
3) Perasaan batin yang ada hubunganya dengan Tuhan, yaitu bagaimana cara manusia mendekatkan diri kepada Tuhan. Hal seperti ini dengan berbagai cara dilakukan sesuai dengan agamanya masing-masing, misalnya agama Islam dengan mendirikan Salat, dan berzikir kepada Allah Swt.

4) Perasaan berdosa, yaitu perasaan seseorang telah sadar telah melakukan kesalahan kepada Allah ataupun lingkunganya, dan berjanji tidak akan mengulangi kembali kesalahankesalahan dan kembali bertaubat kepada Allah.

5) Perasaan takut, yaitu perasaan takut melakukan kesalahan kepada Allah, jika seseorang merasa takut dan merasa selalu diawasi oleh Allah maka ia akan menjauhi segala yang dilarang oleh Allah dan melaksanakan perintahnya.

6) Mengakui kebesaran Tuhan, yaitu seseorang merasa bahwa tidak ada satupun di dunia ini yang menciptakan melainkan Allah Swt dan tidak ada apaapanya di hadapan Tuhan, mengakui kekuasaan Tuhan tidak ada batasnya dan sikap manusia yang percaya bahwa Tuhan Maha Besar dan Maha Berkuasa atas segala sesuatu.

Berdasarkan hasil penelitian novel Lelaki yang Sangat Mencintai Istrinya karya Muhammad B. Anggoro, penulis memberikan saran kepada para pembaca demi terciptanya karya baru. Adapun saran tersebut adalah sebagai berikut:

1. Dengan adanya penelitian ini hendaknya para peneliti selanjutnya terpacu untuk memberikan pemikiran baru dalam usaha menciptakan karya baru dengan meneliti novel-novel lainya guna membangkitkan kembali apresiasi masyarakat luas pada sastra, khususnya novel.

2. Dengan adanya penelitian ini hendaknya para pembaca dapat menerapkan nilai-nilai religius yang terdapat dalam novel Lelaki yang Sangat Mencintai Istrinya karya
Muhammad B. Anggorodalam kehidupan sehari-hari.

\section{REFERENSI}

Adisusilo, Sutarjo. 2013. Pembelajaran Nilai - Karakter. Jakarta: Rajawali Pers.

Ali, Zainuddin. 2007. Pendidikan Agama Islam. Jakarta: PT Bumi Aksara.

Anggoro, Muhammad B. 2012. Lelaki yang Sangat Mencintai Istrinya. Baturetno Banguntapan Jogjakarta: DIVA Press.

Ariyadih. 2013. Nilai religius dalam Novel Opera Van Gontor Karya Amroeh Adiwijaya dan implikasinya Terhadap Pembelajaran Sastra di Sekolah.

Universitas Islam Negeri Syarif Hida yatullah Jakarta. Dilihat pada 10 Oktober 2019. (http://repository. uinjkt. ac. id/dspace/bitstream/123456789/24679 /1/Ariyadih. pdf).

Aryani. 2016. Analisis Unsur Religius Novel Putri Kejawen Karya Novia Syahidah dan Implikasinya dalam Pengajaran Sastra Indonesia. Jurnal Sasindo Unpam, Vol. 3 No. 2. Dilihat pada 21 Oktober 2019. (http://openjournal. unpam. ac. id). Karakter. Jakarta: Rajawali Pers.

Dojosantosa. 1989. Unsur Religius dalam Sastra Jawa. Semarang: Aneka Ilmu.

Elmubarok, Zaim. 2009. Membumikan Pendidikan Nilai. Gegerkalong Hilir Bandung: CV ALFABETA.

Faruk. 2017. Metode Penelitian Sastra Sebuah Penjelajahan Awal. Yogyakarta: Pustaka Pelajar.

Hendy, Zaidan. 1991. Pelajaran Sastra 1. Jakarta: PT Gramedia Widiasarana Indonesia.

Irawan MN, Aguk. 2013. Pesan Al-Quran untuk Sastrawan. Yogyakarta: Jalasutra.

Jauhari, Heri. 2010. Cara Memahami Nilai Religius dalam Karya Sastra.

Bandung: Arfino Raya. 
Meliani, Eka. 2017. Nilai-Nilai Religius dalam Film Hijrah Cinta Karya Hanung Bramantyo dan Implikasinya Sebagai Bahan Pendidikan Karakter di Madrasah Aliyah (Ma) Lampung FKIP: Universitas Lampung. Dilihat pada 18 November 2019.

(http://digilib. Unila. ac. id/28277/3Skripsi\%Tanpa\%Pembahas an. pdf).

Nurgiyantoro, Burhan. 2013. Teori Pengkajian Fiksi. Yogyakarta: Gadja Mada University Press.

Pradopo, Rachmat Djoko. 2013. Beberapa Teori Sastra, Metode Kritik, dan Penerapanya. Yogyakarta: Pustaka Pelajar.

Redaksi PM. 2012. Sastra Indonesia Paling Lengkap. Jawa Barat: Pustaka Makmur.

Risti, Ratnawati V. 2002. Religiusitas dalam Sastra Jawa Modern. Jakarta: Pusat Bahasa.

Saryono, Djoko. 2009. Dasar Apresiasi Sastra. Sanggrahan Sorowajan Yogyakarta: Elmaterapublishing.

Sayuti, Suminto A. 2017. Berkenalan dengan Prosa Fiksi. Yogyakarta: Cantrik Pustaka.

Sehandi, Yohanes. 2018. Mengenal 25 Teori Sastra. Yogyakarta: Ombak.

Siswantoro. 2016. Metode Penelitian Sasrtra Analisis Struktur Puisi. Yogyakarta: Pustaka Pelajar.

Stanton, Robert. 2012. Teori Fiksi Robert Stanton. Yogyakarta: Pustaka Pelajar.

Subur. 2015. Pembelajaran Nilai Moral Kisah. Depok Sleman Yogyakarta: Kalimedia.

Sumardjo, Jakob. 1999. Konteks Sosial Novel Indonesia 1920 - 1977. Bandung: Alumni.

Tolchah, Moch. dkk. 2016. Pendidikan Agama Islam. Malang: Intrans Publishing.

Wicaksono, Andri. 2017. Pengkajian Prosa Fiksi. Yogyakarta: Garudhawaca.

Yanti, Citra Salda. 2015. Religiositas Islam dalam Novel Ratu y ang Bersujud

Karya Amrizal Mochamad Mahdavi. Jurnal semanticscholar. Vol. 3 No. 1. Dilihat pada 3 November 2019. (https://www. semanticscholar. org. pdf).

Zakiyah, Qiqi Yuliati dan Rusdiana. 2014. Pendidikan Nilai. Bandung: CV

\section{Pustaka Setia.}

